ISSN 2449-7479

eISSN 2543-8840

amme.wne.sggw.pl

Annals of Marketing Management \& Economics

Vol. 4, No 1, 2018, 131-147

DOI 10.22630/AMME.2018.4.1.10

\title{
STRATEGIC MANAGEMENT OF TRANSNATIONAL BANKS IN THE INTERNATIONAL MARKET AFTER THE GLOBAL FINANCIAL CRISIS
}

\author{
Dmytro Tsyhaniuk ${ }^{1}$, Vita Boychenko ${ }^{2}$ \\ ${ }^{1}$ Sumy State University, Ukraine \\ ${ }^{2}$ Sumy Department of Taskombank, Ukraine
}

\section{INTRODUCTION}

Continuing crisis in Ukraine's financial and banking system demands not only the need of a radical revision of the state's anti-crisis policy, but also the improvement of scientific and methodological approaches to the formation of post-crisis strategic priorities of banks in the post-crisis period. In particular, there is a need for further study of the issues related to the influence of combinations of different types of financial crises on the credit and investment market and the global banks' strategic vectors on it, the rationale for post-crisis changes in strategic determinants of the activities of different types of banks in different segments of credit and investment market, the formation of an effective tools' portfolio in post-crisis strategic bank's management, etc. A prerequisite for solving the above-mentioned issues is the development of scientific and methodological approaches to the formation and implementation of strategies of banks in the credit and investment market during the recovery of the economy after the financial crisis.

During the liberalization of the capital markets, the countries significantly reduced or removed at all the restrictions on the banking sector, giving foreign banks greater access to the domestic market, both in terms of investment and in terms of servicing domestic economic agents. As with other forms of capital liberalization, the presence of foreign banks may increase the presence of international capital, increase the level of real investment and economic growth in the capital recipient country. 


\section{METHODOLOGY AND RESULTS}

Quite often, the arrival of foreign banks leads to increased competition in the domestic market, increased financial and economic efficiency of economic entities, and reduced transaction costs in financial intermediation [Stezhko 2009]. In addition, the presence of foreign banks stimulates the improvement of control and oversight bodies in the country [Berger et al. 2000]. However, the 2008 financial crisis has called into question the positive impact of transnational banks on the country's economy. The collapse of Lehman Brothers in September 2008 led to a reduction in the global liquidity of the world economy, which led to a reduction in the international activity of banks, especially in the countries with emerging markets. From 2007 to 2008 international bank loans decreased by $80 \%$ : from 500 billion to 100 billion USD. This led to a sharp decline in production in 2009, especially in the countries with emerging markets [Calvo 1996]. Exit of international banks from emerging markets has caused a collapse in domestic asset prices and the destruction of domestic financial systems in these countries.

We consider next hypotheses about transnational banks behaviour just after the crisis.

1. Transnational banks will leave countries with greater risks and lower profitability, they will search for more effective markets that let them earn more profits.

2. Transnational banks will increase their presence in those countries, where crisis had the lowest impact on economy, because credit and regulatory risks in such countries would be lower.

3. The effectiveness of monetary transitional mechanism is important factor, that can influence transnational banks behaviour in contrast to financial and macroeconomic factors.

For the purposes of this paper, we examine just European countries and bank, because they have crucial impact for the most Eastern European countries and their banking systems, including Ukraine.

Considering the fact that the behaviour of transnational groups in different countries differed in terms of the development of their subsidiaries, we will conduct an analysis of the relationship between the presence of foreign capital in the banking system and individual indicators of economic development and development of the banking system. We understand that there were many non-financial factors stimulating crisis (e.g. lack and fall of consumer confidence, chain reactions in consumers and banks behaviour and so on), but we opine that every non-financial impact has its financial interpretation, so it can be counted by some financial indicator. For that purpose we consider the following groups of indicators:

1. Indicators of profitability of banking activities:

- return on assets;

- return on capital;

- net interest margin;

- commission income;

- the average level of credit rates.

2. Indicators of financial stability of the banking system:

- the ratio of regulatory capital to risk-weighted assets;

- the ratio of regulatory capital of the first level to risk-weighted assets; 
- the ratio of non-performing loans excluding reserves to equity;

- the ratio of non-performing loans to total gross loans;

- the ratio of loans by sector of the economy in total gross loans;

- the ratio of interest margin to gross income;

- the ratio of non-interest expenses to gross income;

- the ratio of liquid assets to total assets;

- the ratio of liquid assets to short-term liabilities;

- the ratio of net open position in foreign currency to capital;

- the ratio of capital to assets;

- the ratio of open positions to capital.

3. Indicators of ease of doing business (doing business ranking):

- registration of enterprises;

- obtaining permits for construction work;

- registration of property;

- obtaining loans;

- protection of minority investors;

- taxation;

- international trade;

- resolution of insolvency issues.

4. Indicators of the speed of the country's exit from the financial crisis:

- GDP growth;

- increase in the deposit portfolio;

- increase in the loan portfolio;

- increase in Z-score;

- the growth of assets of the banking system;

- decrease in the volume of state support to banks;

- increase in international reserves;

- increase in public debt.

5. Indicators of the financial crisis of different types:

- the ratio of customer deposits to total gross loans (excluding interbank loans);

- the ratio of liquid assets to short-term liabilities;

- the ratio of net open position in foreign currency to capital;

- the ratio of non-performing loans excluding reserves to equity (the right scale);

- the ratio of public debt to GDP;

- the consumer price index;

- the ratio between external and internal public debt;

- the ratio of corporate debt to GDP;

- the exchange rate of the national currency to the USD;

- the equity of foreign trade balance;

- the balance of the financial account;

- the volume of international reserves of the central bank;

- the ratio of net open position in foreign currency to capital;

- the ratio of the volume of foreign direct investment to GDP;

- the discount rate;

- the difference between the central bank discount rate and LIBOR. 
We selected the following factors as indicators of the presence of foreign banks:

- increase in loans from non-resident banks;

- increase in the share of external loans and deposits of banks in loans and deposits of the entire banking system;

- increase in the share of assets of foreign banks in the aggregate assets of the banking system;

- increase in the share of foreign banks (number) in the banking system.

During 2008-2011 many regulations were done both - on the local levels and Central European Bank level. For example in 2009-2013 European Parliament adopted CRD II (2009), III (2010) and IV (2013) that made banks to modify their reserve politics. But we think that those changes will have strategic impact, that can be analysed after at least 5 years of work. Anyway, those regulations were initiated by crisis consequences, so we cannot consider them separately, but we will analyse financial factors that caused regulation measures and were influenced by them. That let us to avoid difference in impact that Basel 2.5 and Basel III had in different countries.

The main method of analysis we use is Pearson correlation analysis. We consider that crisis that started in 2008 in Europe had its peak in 2010-2011 and starting from 2011, in most countries we can observe the beginning of recovery. So in that opinion we can take 2011 as the start point of post-crisis recovery.

In European countries, the decline in external assets and liabilities reached $20 \%$ over a fairly short period of time (Fig. 1).

As can be seen from Fig. 1, the largest value of external assets and liabilities was observed in November 2008, followed by a significant decline. In our opinion, such a decline was a reflection of the policy of European transnational banks, aimed at supporting the main "parent" business.

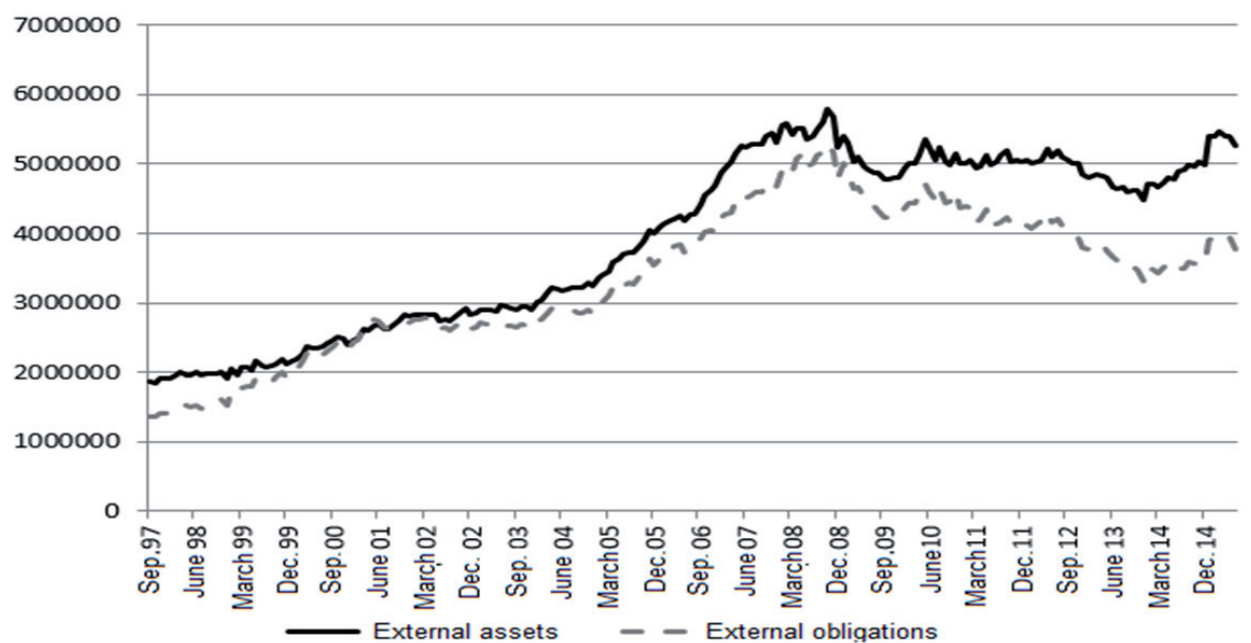

FIG. 1. International position of banks in EU countries in 1997-2014 in million EUR

Source: the authors based on European Central Bank datebase. 
Researchers [Claessens and van Horen 2011, Dekle and Lee 2012] note that in the early 2000s the expansion of the international network of banks from Europe took place gradually. In 1997, foreign assets and liabilities of European banks amounted to about 2 trillion EUR. Over the next 6 years, they increased by 50\% and reached almost 3 trillion EUR for 2003. The reasons for such a gradual increase were both the crisis of dotcoms, which made banks more prudent in choosing industries for lending and investment, and the underdevelopment of economies in post-soviet countries. Ukraine, Belarus and Russia - the largest post-soviet economies have suffered the crisis of 1998 that hit their financial sectors, reducing their financial and investment attractiveness for European banks. The countries of central, eastern and southern Europe also experienced severe market transformations. 2003 marked the end of the period of uncertainty. In Southern Europe military operations were over, the countries of Central Europe successfully carried out monetary reforms and began to develop rapidly. Ukraine, Russia and Belarus also recovered from the crisis and began to demonstrate real progress in economic development. It was in 2003 that the active expansion of European transnational banks began. In Figure 1 this is noticeable since the end of 2002, when external assets started to grow at a faster pace than the commitments, which meant the active development of overseas branches and subsidiaries with donor funding from parent banks.

In the inter-crisis period - starting from 2003 (the end of the crisis of dotcoms) to the beginning of 2008 (the beginning of the global financial crisis), the foreign assets of banks in the European Union increased from 2.9 trillion EUR to 5.5 trillion EUR, or almost by $90 \%$, with a slightly lagging growth rate of external corporate debt. A similar situation was observed during 1999-2001 before the dotcoms crisis. This testifies to the policy of active expansion conducted by transnational banks.

With the beginning of the crisis of 2008-2009, the volume of external assets and external liabilities almost equalled, indicating the transfer of external units to self-financing. At the same time, the growth of such assets has ceased, moreover, in fact for one year (from November 2008 to November 2009), foreign assets decreased from 5.8 trillion EUR to 4.8 trillion EUR, i.e. by $17.2 \%$. It should be added that the growth of lending to foreign banks in the period 2003-2008 was carried out quite actively. Almost half of the external assets of the banks that carried out the expansion were issued as loans (Fig. 2).

And such as in the case of assets, there is a decrease in lending - from 2.4 trillion EUR to 1.9 trillion EUR for the period from 01.10 .2008 to 01.10 .2009 or by $21 \%$. At the same time, the volumes of lending by non-resident banks during the period of expansion grew more than two times - from 1.1 trillion EUR to 2.4 trillion EUR, or by $120 \%$.

The study of the causes and consequences of the global financial crisis [Claessens et al. 2001, Collyns and Kincaid 2003, Bussiere 2006, Dell' Ariccia et al. 2008, Allen et al. 2009, Reinhart and Rogoff 2009, Dobravolskas and Seiranov 2011, Claessens and Ayhan 2013] shows that most transnational banks suffered from the initial shock of liquidity, especially as reflected in the balance sheets of parent banks, which in turn led to a reduction in lending in foreign markets. Such a reduction in lending, especially in significant volumes, was observed in relation to European banks in the markets of Eastern Europe, Asia and Latin America.

Separate scholars [Claessens and van Horen 2011] indicate that there is a close link between the volume of reduction in lending of a specific transnational bank and the level 


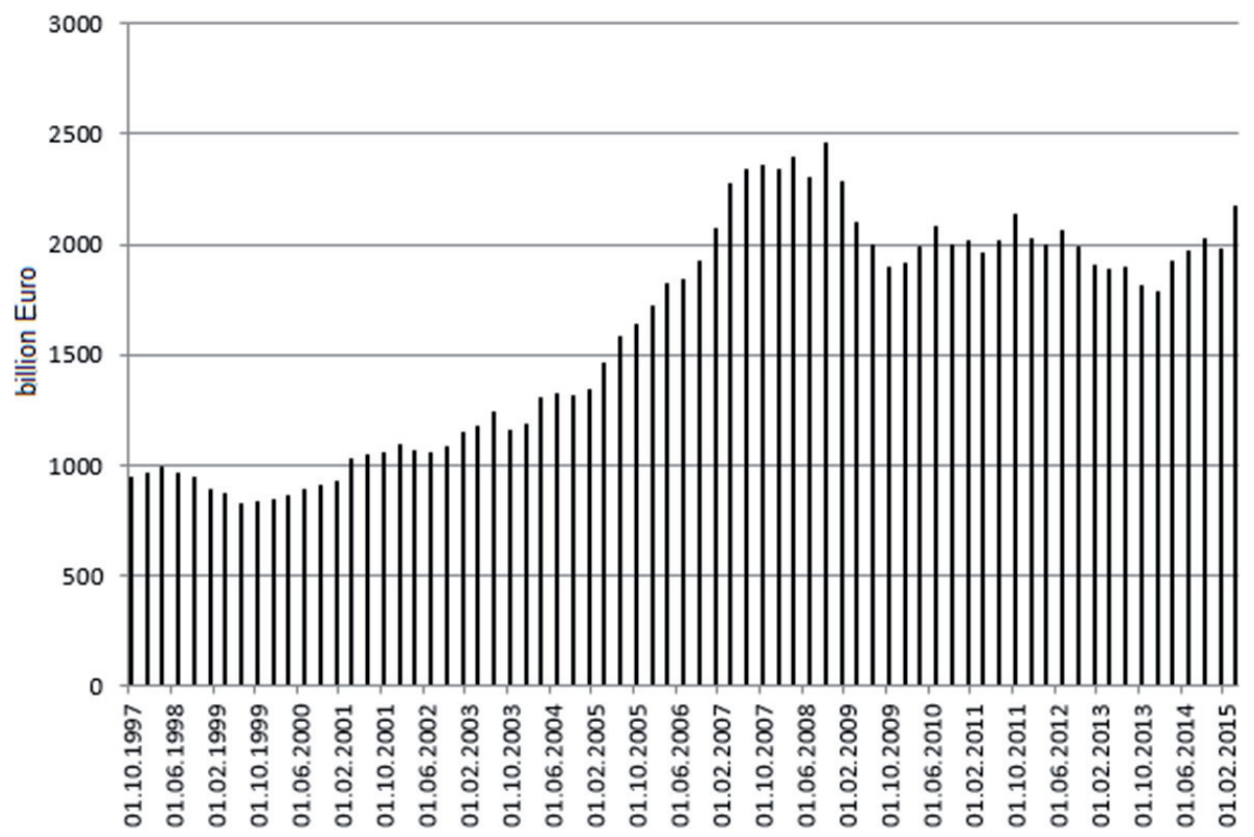

FIG. 2. Dynamics of loans granted by non-resident banks in the European Union in 1997-2014 in million EUR

Source: the authors based on European Central Bank database.

of public debt in the country where the headquarters of such a bank is located. Banks from European countries, where the high level of public debt was observed, reduced lending in foreign banking markets to a greater extent than banks with headquarters in countries with low levels of public debt.

Such an effect can be explained in the following way. With the beginning of the financial crisis, banks began to feel the acute shortage of liquidity. To cover the lag of liquidity, state governments have traditionally resorted to the same monetary tools. Basically, these are refinancing tools. However, for their application, especially on a large scale, considerable financial resources are required. It is obvious that countries that already had a high level of public debt were limited in their ability to quickly raise additional capital, and that which was involved was rather expensive. Thus, transnational banks were forced to assess the difference in the cost of supporting their own banking business by attracting additional resources from the state and by releasing resources from their foreign assets. This justifies the fact that for banks from countries with a high level of public debt it was more profitable to reduce the amount of support for their own franchise to save the parent bank rather than to attract additional support for liquidity from the state.

As to the commitments, during the period of expansion, they increased almost two times - from 1.6 trillion EUR in the beginning of 2003 to 3.1 trillion EUR at the end of 2008 , or by $94 \%$ (Fig. 3).

The decrease in the total volume of liabilities of non-resident banks was more rapid than the volume of assets - from 5.2 to 4.2 trillion EUR, or by $19.2 \%$ over the period from 


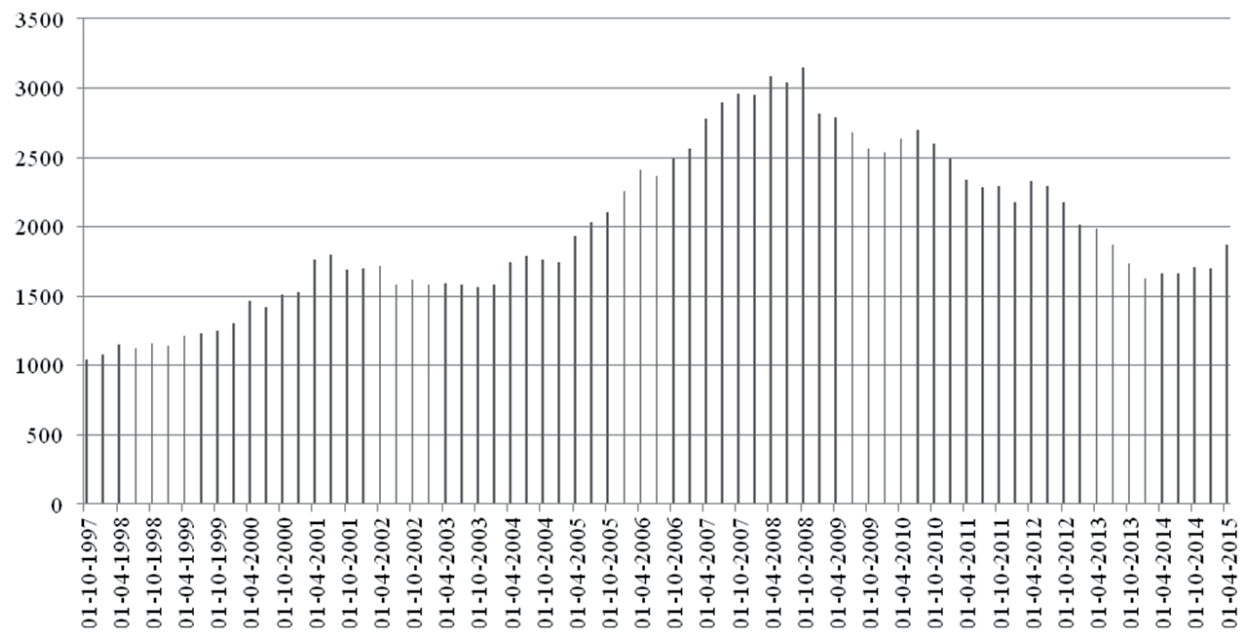

FIG. 3. Dynamics of deposits of non-resident banks in EU countries, in 1997-2015 in billion EUR Source: built by authors based on European Central Bank database.

November 2008 to November 2009. At the same time, we can state that the financial and economic crisis has significantly impacted on the liquidity of balances of foreign banks. Thus, during the year of the crisis (from November 2008 to November 2009), the reduction of the deposit base was $18.5 \%$, and in the next 5 years, another $36.7 \%$.

In a situation where banks are experiencing a sharp outflow of resources, banks tend to reduce lending. The sharp contraction of bank liabilities (for example, the withdrawal of banks from the market, accompanied by a reduction in liabilities for which the required reserves are calculated) creates the need to find new sources of resources that would be able to cover the lack of liquidity, and subject to a reduction of the interbank credit market this problem can be solved only by reducing the volume of lending, otherwise the bank will not be able to meet the reserve requirements.

The study of the American banking market and the international activities of American banks during the 2008-2009 crisis shows that the crisis in Africa and Asia has led to a significant reduction in lending, while in the American banking market, the reduction in lending was not so high [Frankel and Saravelos 2012 see also: Bech 2016, Barrel et al. 2010, Cetorelli and Goldberg 2010, Popov and Udell 2010, Babecky et al. 2012]. As for European banks, they have become leaders in reducing lending in the US and Latin American markets.

In both of the considered crises (2001-2002 and 2008-2009), there is a levelling of volumes of foreign assets and liabilities of transnational banks, indicating the tendency of transnational banks to withdraw their own investments from subsidiary banks during the crisis and at its completion. Let us analyse in more detailed data on the international financial activity of individual banking groups.

The most interesting for the analysis in this case is the Raiffeizen Bank International group, as this group is one of the most widespread and successful international banking 
groups in the former USSR. Let's consider the dynamics of the assets of the banks of the Raiffeizen International Group by regions (Fig. 4).

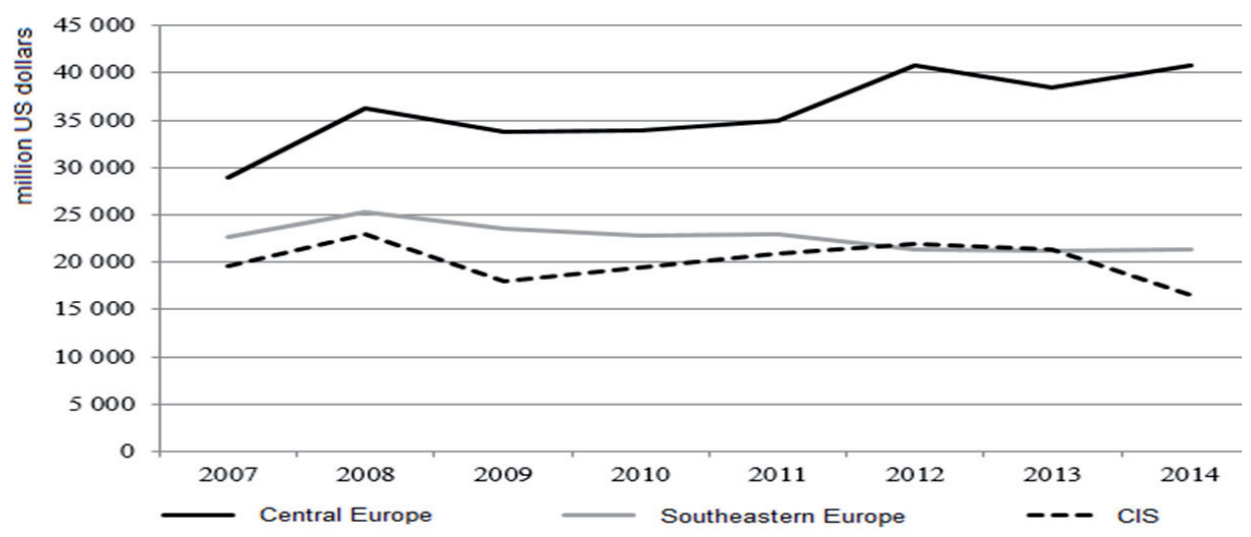

FIG. 4. Assets of the Raiffeizen International Group banks by regions in 2007-2011 in million USD Source: the authors based on Official consolidated annual report of the Raiffeisen Bank International.

As we see from Figure 4, the Raiffeizen Bank International Group ceased to pursue the expansion policy in 2007. Starting from 2008, the bank has virtually ceased to expand its business in Southeast Europe and the CIS. Instead, there is an increase in the assets of Central Europe, that is, in Austria, where the parent bank is located. This again leads us to the hypothesis that in the times of crisis and post-crisis recovery, large transnational banks prefer to develop and rescue their main business, while neglecting the interests of the regional divisions. An illustration of this policy is the volume of external debt of PJSC "Raiffeisen Bank Aval" (Ukraine), which was mainly formed by borrowing from the parent bank (Fig. 5). 


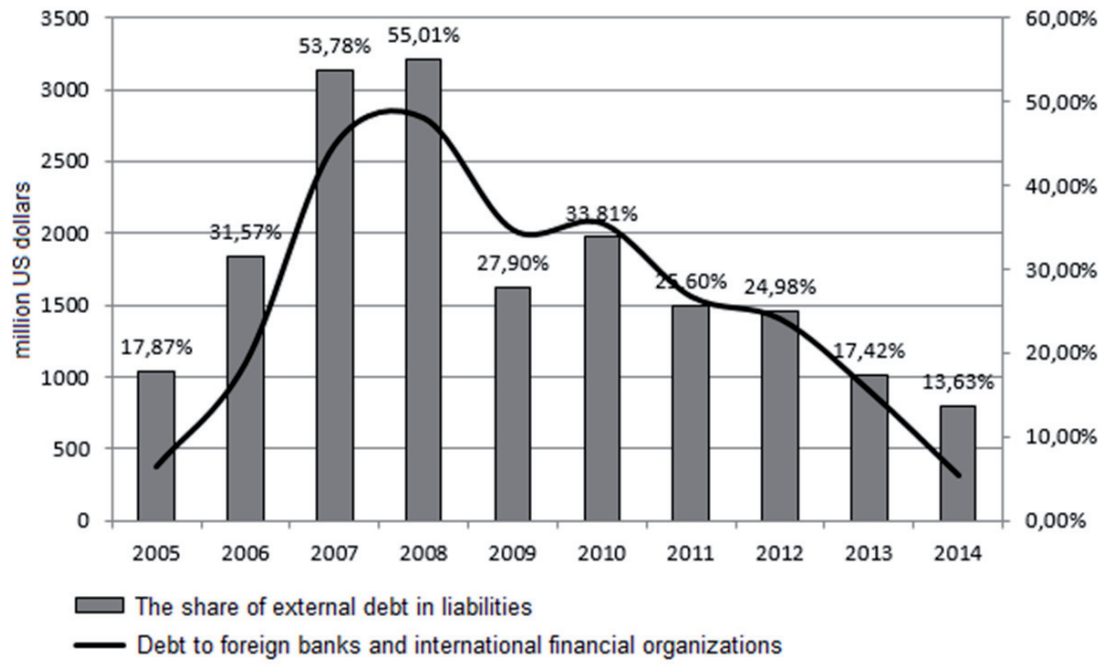

FIG. 5. Dynamics of external debt of PJSC "Raiffeisen Bank Aval” (Ukraine)

Source: the authors based on Official consolidated annual report of the Raiffeisen Bank International.

Starting from 2009, and despite the devaluation of the Ukrainian hryvnia, the share of external debt in the structure of the bank's liabilities decreased twice within the year, and

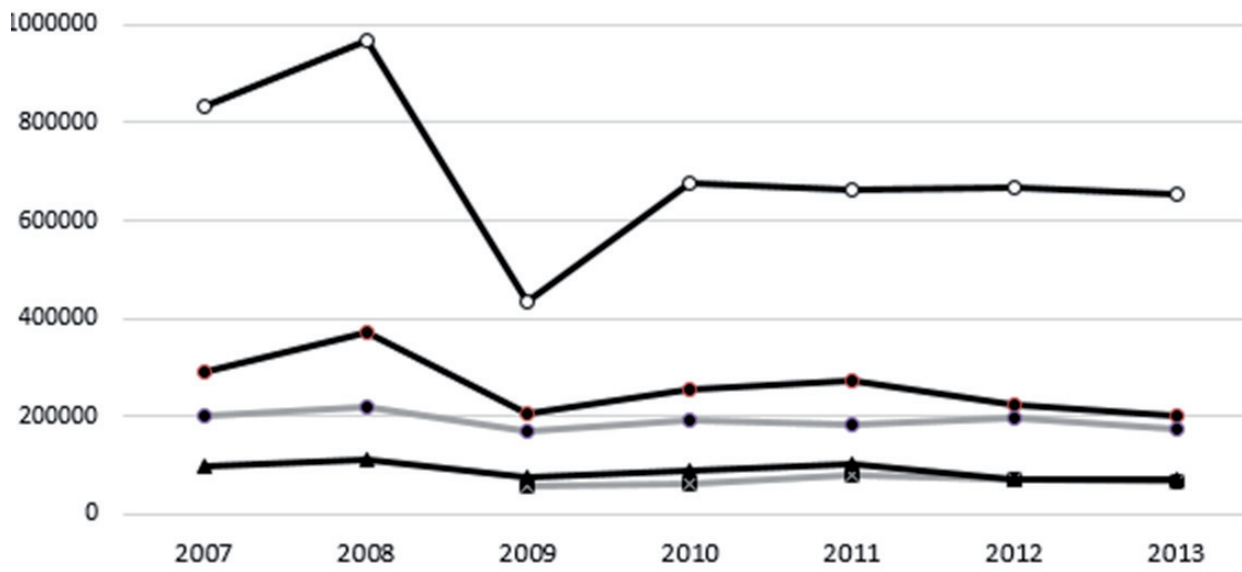

$\rightarrow$ Domestic market (France, Belgium, Luxembourg, Italy)

$\rightarrow-O t h e r$ Europe (Great Britain, the Netherlands, other countries of Western, Central and Eastern Eurc

$\rightarrow-$ Africa and the Mediterranean

$\rightarrow$ America

- Asia and Oceania

FIG. 6. Dynamics of assets of the BNP Paribas Group by country of placement in 2007-2013

Source: the authors based on Official consolidated annual report of the BNP Paribas Group. 
even more than twice in the next 5 years. In fact, the Ukrainian branch of Raiffeizen International has almost lost the support of the parent company. During this period, one should also note the change in the bank's business model, which, from a universal one, actually turned into a corporate bank. Another vivid example of a change in the vector of development is demonstrated by the BNP Paribas Group (France). In the pre-crisis period of 2006-2007, the BNP Paribas Group has grown its assets in Central and Eastern European countries by $27 \%$. Analysing the international activity of the group during the last two crises (2008-2009 and 2012-2013), it can be concluded that the largest group reduced its assets in 2008-2009 in local European markets and in European countries (Fig. 6) .

As we see from Figure 6 in the post-crisis period, the BNP Paribas Group actively resumed assets on the so-called domestic market, which includes France, Belgium, Luxembourg and Italy. At the same time, assets in other regions of the world have not undergone significant global changes. Let's analyse the activity in the international markets of another large banking group in Europe - UniCredit Group. This group is represented in 18 countries of Europe (total 104 subsidiaries and representative offices), in 8 countries of Asia and Oceania (9 subsidiaries and representative offices), in 3 countries of America (4 subsidiaries) and in 3 countries of Central Asia and Africa (3 subsidiaries). In Ukraine, the group until 2017 was represented by PJSC "Ukrsotsbank", which has a long and successful history of activities in the market of banking services of Ukraine. In 2016, the UniCredit Group decided to sell its Ukrainian subsidiary company. The new owner of PJSC "Ukrsotsbank" for today is Alfa Group. Table 1 shows the dynamics of assets of regional banks of the UniCredit Group in the countries of Eastern and Central Europe.

TABLE 1. Risk weighted assets of UniCredit Group regional units, in 2007-2016 in millions EUR at the end of the year

\begin{tabular}{|l|c|c|c|c|c|c|c|c|c|c|}
\hline \multirow{2}{*}{ Country } & \multicolumn{10}{|c|}{ Years } \\
\cline { 2 - 13 } & 2007 & 2008 & 2009 & 2010 & 2011 & 2012 & 2013 & 2014 & 2015 & 2016 \\
\hline Poland & 25726 & 22544 & 22011 & 22969 & 23234 & 25185 & 24162 & 25894 & 25810 & 25649 \\
\hline Turkey & 10300 & 9382 & 13143 & 16870 & 18519 & 21020 & 19144 & 24367 & 28767 & 29092 \\
\hline Russia & 9048 & 11596 & 9560 & 11787 & 14731 & 17205 & 16808 & 15690 & 15080 & 14191 \\
\hline Ukraine & 0 & 4189 & 4324 & 4076 & 4158 & 3764 & 3543 & 2741 & 1992 & $1917 *$ \\
\hline Croatia & 7525 & 8460 & 7731 & 8707 & 9588 & 9038 & 7906 & 7850 & 7594 & 7559 \\
\hline Kazakhstan & 5725 & 5571 & 4809 & 4687 & 4391 & 0 & 0 & 0 & 0 & 0 \\
\hline Bulgaria & 2685 & 3916 & 4472 & 4285 & 4411 & 5002 & 4969 & 5118 & 5060 & 4876 \\
\hline Romania & 2479 & 3300 & 2878 & 3327 & 3864 & 4015 & 4016 & 4831 & 5389 & 5491 \\
\hline Hungary & 4268 & 4677 & 4223 & 4079 & 4270 & 4052 & 3669 & 3967 & 3979 & 3869 \\
\hline $\begin{array}{l}\text { Czech } \\
\text { Republic }\end{array}$ & 7756 & 7797 & 7459 & 7921 & 7595 & 7553 & 7714 & 8532 & 9612 & 10153 \\
\hline Slovakia & 2352 & 2843 & 2778 & 3318 & 3143 & 2811 & 2759 & 3175 & 3555 & 3567 \\
\hline Bosnia & 1235 & 1437 & 1835 & 1933 & 1533 & 1577 & 1528 & 2394 & 2729 & 2653 \\
\hline Slovenia & 1531 & 2020 & 1997 & 2149 & 2278 & 1855 & 1515 & 1251 & 1119 & 1276 \\
\hline Serbia & 731 & 753 & 1611 & 1749 & 1838 & 1743 & 1763 & 2452 & 2801 & 2547 \\
\hline
\end{tabular}




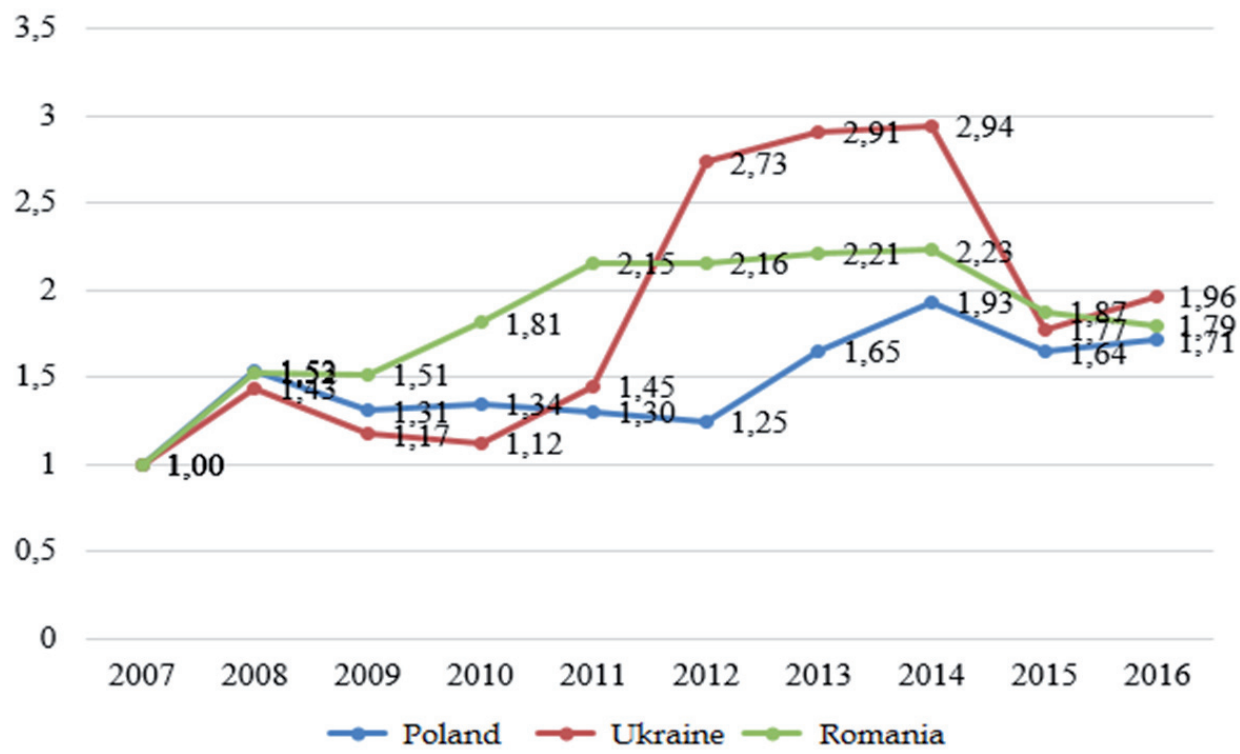

FIG. 7. The index of growth of assets of banks belonging to the Credit Agricole Group in the countries of Central and Eastern Europe, base year - 2007

Source: the authors based on (Official consolidated annual report of the Crédit Agricole Group.

\footnotetext{
* data are presented at the end of the third quarter of 2016, because then the group left the Ukrainian banking services market

Source: the authors on based on Official consolidated annual report of the UniCredit Group.
}

As we see, the decline in assets in the post-crisis period occurred only in Bosnia, Bulgaria, Kazakhstan and Ukraine. In all other countries, volumes of assets continued to increase in the post-crisis period. This behaviour of the international transnational banking group contradicts the hypothesis of withdrawal of capital from subsidiaries during the crisis; therefore, to explain this fact, it is necessary to analyse additional factors that may influence the decision to increase or decrease the presence of a transnational bank in the market of a particular country.

Let's consider the dynamics of development of subsidiary banks of another large transnational banking group, Credit Agricole Group, which has 2,771 local banks in France and more than 1,000 units in 52 countries of the world (Fig. 7). As we can see from this Figure, in 2009 there was a short-term and insignificant decline in the assets of banks in Eastern Europe (other countries were not analysed due to the insignificant presence of the group or lack of necessary statistics).

At the same time, the growth in Ukraine began in 2011 and in Poland as early as 2013. The associated company in Romania has more quickly emerged from the crisis because since 2010 the assets have already grown. However, Credit Agricole Group did not dem- 


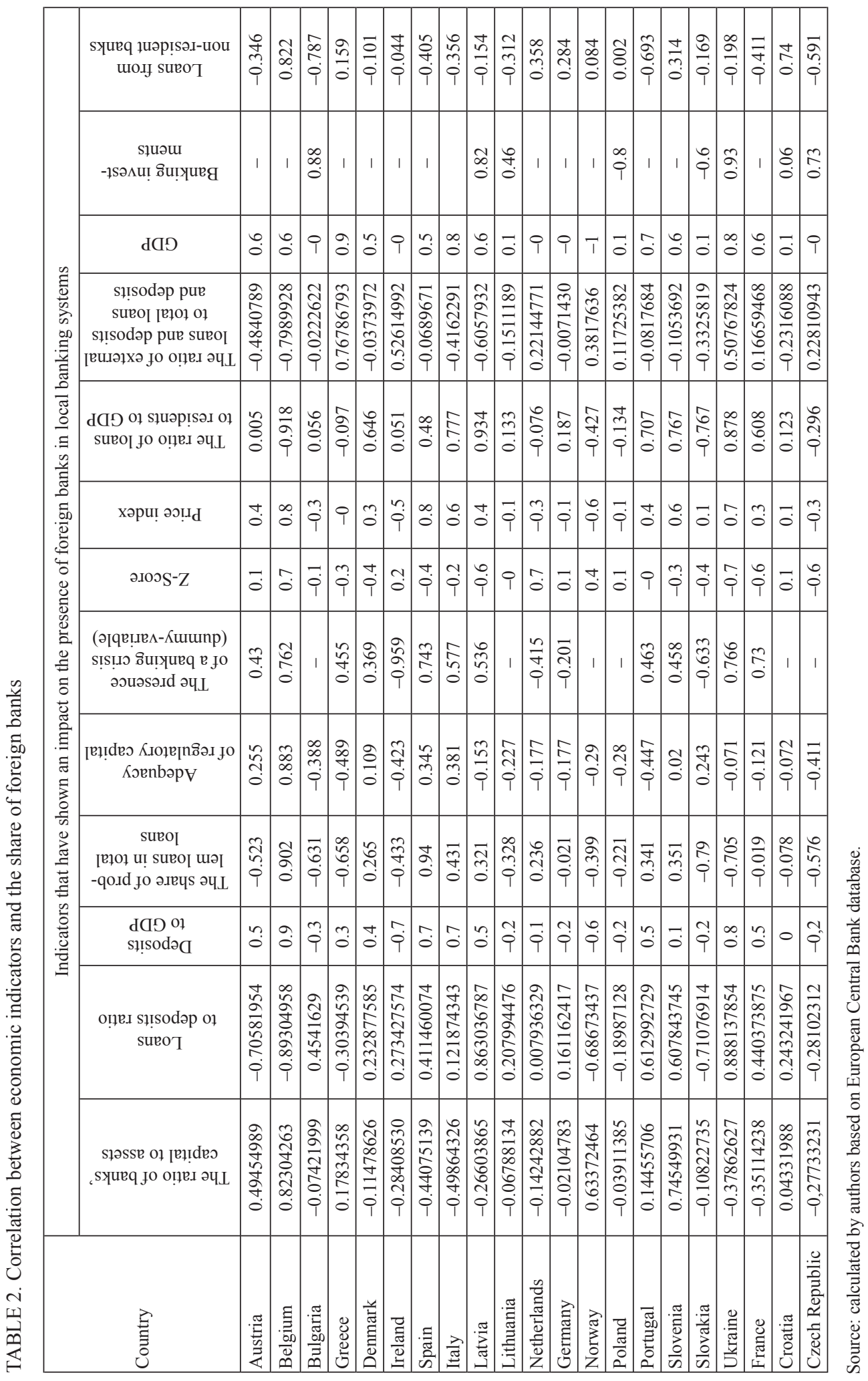


TABLE 3. Results of the analysis of the response of transnational banks to the structure of the complex financial crisis (2007-2008), the rate of recovery of economies and banking systems in Europe in the post-crisis period (2009-2011)

\begin{tabular}{|c|c|c|c|c|c|c|c|c|c|c|c|c|}
\hline \multirow[b]{2}{*}{ Country } & \multicolumn{4}{|c|}{$\begin{array}{l}\text { The presence } \\
(+/-) \text { of the } \\
\text { financial crisis } \\
\text { of the corre- } \\
\text { sponding type in } \\
\text { 2007-2008) }\end{array}$} & \multicolumn{4}{|c|}{$\begin{array}{l}\text { Indicators of the speed } \\
\text { of the post-crisis } \\
(2009-2011) \text {, the } \\
\text { recovery of the economy } \\
\text { of banking systems } \\
\text { in Europe }\end{array}$} & \multicolumn{4}{|c|}{$\begin{array}{l}\text { Indicators of the reaction } \\
\text { of transnational banks to the structure } \\
\text { of an integrated financial crisis } \\
\text { and the speed of post-crisis recovery } \\
\text { of economies and banking systems } \\
\text { in Europe }\end{array}$} \\
\hline & 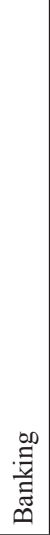 & 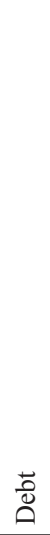 & 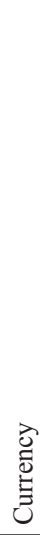 & 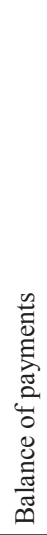 & 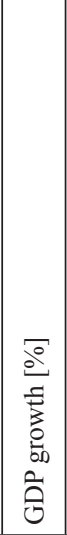 & 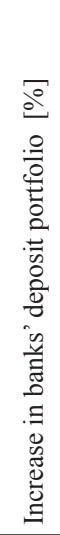 & 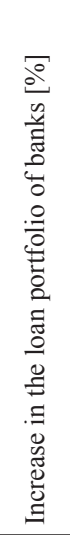 & 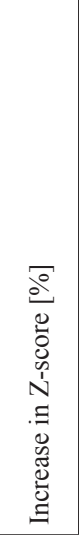 & 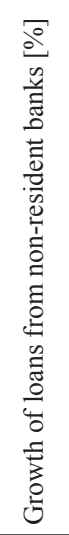 & 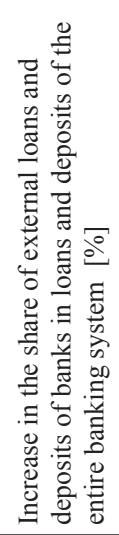 & 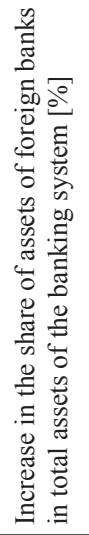 & 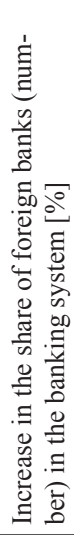 \\
\hline Austria & + & - & - & - & +8 & -7 & -2 & -15 & -16 & -20 & -12 & 0 \\
\hline Belgium & + & - & - & - & +9 & +1 & -6 & +18 & -15 & -17 & -2 & 0 \\
\hline Bulgaria & - & - & - & - & +9 & +7 & -5 & +4 & -32 & -12 & -11 & -6 \\
\hline Greece & + & + & - & - & -13 & -5 & +33 & -100 & +46 & -21 & -36 & +14 \\
\hline Denmark & + & - & - & - & +7 & -19 & -7 & +19 & -13 & -10 & -10 & -11 \\
\hline Estonia & + & - & - & - & +18 & -3 & -23 & +641 & +23 & +216 & -2 & 0 \\
\hline France & + & - & - & - & +6 & -4 & +2 & -5 & -2 & +16 & 0 & -20 \\
\hline Finland & + & - & - & - & +9 & -1 & +4 & -35 & +15 & -30 & +7 & 0 \\
\hline Germany & + & - & - & - & +10 & -2 & -14 & +8 & -15 & -25 & -8 & 0 \\
\hline Czech Republic & - & - & - & - & +11 & -2 & +7 & -1 & +7 & -13 & -1 & -4 \\
\hline Croatia & - & - & - & - & -1 & +13 & +5 & -1 & +18 & -46 & 0 & +9 \\
\hline Ireland & + & + & - & - & +2 & -10 & -32 & +359 & -25 & -13 & 0 & -3 \\
\hline Italy & + & - & - & - & +4 & -4 & +8 & -20 & -8 & +11 & 0 & +10 \\
\hline Latvia & + & - & - & - & +9 & -1 & -25 & +92 & -2 & +31 & -12 & -11 \\
\hline Lithuania & - & - & - & - & +16 & -6 & -29 & +246 & +26 & +22 & -3 & -4 \\
\hline Netherlands & + & - & - & - & +4 & 0 & -2 & +16 & +7 & -21 & +166 & +7 \\
\hline Norway & - & - & - & - & +29 & -3 & -2 & +17 & -1 & +20 & -6 & 0 \\
\hline Portugal & + & + & - & - & 0 & 0 & -2 & -21 & -19 & -14 & -8 & -3 \\
\hline Poland & - & - & - & - & +20 & +6 & +9 & +6 & -1 & +10 & -1 & -3 \\
\hline Serbia & - & - & - & - & +9 & +12 & +12 & -1 & +73 & -10 & +3 & +5 \\
\hline Slovenia & + & - & - & - & +2 & +3 & -1 & -14 & -6 & -50 & -4 & 0 \\
\hline Slovakia & - & - & - & - & +10 & -12 & +4 & +11 & +23 & +3 & +1 & -8 \\
\hline Spain & + & + & - & - & -1 & -5 & -3 & -15 & -5 & -5 & 0 & +29 \\
\hline European Union & + & + & - & - & +6 & -7 & -4 & -16 & -2 & +14 & - & - \\
\hline \multicolumn{13}{|c|}{ Countries outside the European Union: } \\
\hline Turkey & + & - & - & - & +26 & -2 & +36 & -14 & -6 & -37 & 0 & -8 \\
\hline Ukraine & + & + & + & + & +39 & -5 & -22 & +33 & +14 & -18 & -11 & +2 \\
\hline
\end{tabular}

Source: calculated by authors based on European Central Bank database. 
onstrate the volume of additional injections into its associated companies, and in fact, this increase was provided by the forces of the subsidiaries themselves.

As a result, we note that among all the certain factors in the greatest statistical significance are the following:

- GDP growth;

- increase in the loan portfolio;

- increase in the deposit portfolio;

- increase in Z-score (Tables 2 and 3).

These factors as well as the presence of several types of crises have a great impact on the behaviour of foreign banks in local markets. In some cases, when the dynamics of relevant factors indicated the need to exit the market (there was a reverse trend in some countries), transnational banks increased their presence. An in-depth analysis of the actions of regulators in the crisis period showed that these countries demonstrated a high degree of efficiency of the transmission mechanism of monetary policy, that is, in such countries the market reacted quickly enough to the implemented regulatory measures. In our opinion, this contributed to the leaving of transnational banks in such countries, even with unfavourable dynamics of relevant factors.

\section{CONCLUSIONS}

The hypothesis regarding the post-crisis change in strategic priorities of transnational banks has been checked on the data of Ukraine and other European countries. An analysis of the policy of the four largest European transnational banking groups (Raiffeizen International, BNP Paribas, Crédit Agricole and UniCredit) to expand/narrow their activity outside the bank of the country for 2000-2016 has shown that in the pre-crisis period, all these banking groups actively expanded their the net abroad (for example, only in 2006-2007 the BNP Paribas group increased its assets in Central and Eastern European countries by $27 \%$ ), during the crisis, they contracted foreign assets and suspended further expansion of the network (for example, during the in 2008, the assets of the Raiffeizen International group in Central Europe declined by $9 \%$, in the South East - by $15 \%$, and in the CIS countries - by $23 \%$ ), and in the post-crisis period there was a clear general tendency to change the strategic priorities of these banking groups absent (different groups in different countries behaved differently).

In order to identify the factors that influence the strategy of transnational banks in the post-crisis period, the work analyses the correlation between the volumes of assets of foreign banks in the banking systems of European countries in 2009-2011 and the following factors: 5 indicators of return banking activity in the country; 12 indicators of financial stability of the banking system; 8 indicators of ease of doing business; 8 indicators of the rate of exit of the country from the financial crisis; 12 indicators of the availability of various types of financial crisis. 
Calculations showed no explicit link between the presence of foreign banks in the banking system and performance are the ease of doing business and the financial stability of banking systems. At the same time, speed indicators withdrawal from the financial crisis and the simultaneous presence of the financial crisis different types of average correlation coefficient was high $\left(\mathrm{R}^{2}>0,7\right)$ for the majority of countries surveyed.

In addition, calculations have been made of the time lag between the use by regulators (European Central Bank and national central banks) of these countries of anticrisis measures and the change in the target indicators for which these measures were directed, and the dependence of changes in the volumes of assets of foreign banks in the banking systems of these countries has been determined from the duration this time interval.

The calculations have shown that in countries where the transmission mechanism of monetary policy operates quickly and efficiently, multinational banks rarely decide to leave the market of the host country. Thus, in the post-crisis period, for multinational banks, when choosing to increase/decrease the volume of assets in the banking system of the host country, the prevailing factors are: 1) the number of types of crises deployed in the country simultaneously (the structure of the complex financial crisis); 2) the rate of recovery of economies and banking systems of these countries in the post-crisis period; 3) the effectiveness of the transmission mechanism of monetary policy in these countries.

\section{REFERENCES}

ALLEN F., BABUS A., CARLETTI E., 2009. Financial Crises: Theory and Evidence, Annual Review of Financial Economics, 1, 97-116.

BABECKÝ J., HAVRÁNEK T., MATĚJƯ J., RUSNÁK M., ŠMÍDOVÁ K., VAŠÍČEK B., 2012. Leading Indicators of Crisis Incidence: Evidence from Developed Countries. Czech National Bank, mimeo.

BARRELL R., DAVIS E.P., KARIM D., LIADZE I., 2010. Bank Regulation, Property Prices and Early Warning Systems for Banking Crises in OECD Countries. Journal of Banking \& Finance, 34(9), 2255-2264.

BECK T., 2016. Regulatory Cooperation on Cross-Border Banking - Progress and Challenges After the Crisis, National Institute Economic Review, 235(1).

BERGER A.N., DEYOUNG R., GENAY H., UDELL G.F., 2000. Globalization of Financial Institutions: Evidence from Cross-Border Banking Performance. RB Chicago Working Paper 1999-25.

BUSSIERE M., FRATZSCHER M., 2006. Towards a New Early Warning System of Financial Crises. Journal of International Money and Finance, 25(6), 953-973.

CALVO G., LEIDERMAN L., REINHART C., 1996. Inflows of Capital to Developing Countries in the 1990s, Journal of Economic Perspectives, 10(2), 123-139.

CETORELLI N., GOLDBERG L.S., 2010. Global Banks and International Shock Transmission: Evidence from the Crisis. NBER Working Papers 15974, National Bureau of Economic 
Research, Inc., retrived from http://ideas.repec.org/p/nbr/nberwo/15974.html [accessed: 15.03.2018].

CLAESSENS S., van HOREN N., 2011. Foreign Banks: Trends, Impact and Financial Stability. DNB Working Papers 330, Netherlands Central Bank, Research Department, retrived from http://ideas.repec.org/p/dnb/dnbwpp/330.html [accessed: 15.03.2018].

CLAESSENS S., AYHAN K.M., 2013. Financial Crises: Explanations, Types, and Implications, IMF Working Paper 13, 28.

CLAESSENS S., DORNBUSCH R., PARK Y.-C., 2001. Contagion: Why Crises Spread and How This Can Be Stopped (in:) S. Claessens and K. Forbes (eds), International Financial Contagion, Kluwer Academic Publishers, 19-41.

COLLYNS C., KINCAID G.R., 2003. Managing Financial Crises: Recent Experience and Lessons for Latin America. IMF Occasional Paper 217, International Monetary Fund, Washington.

DEKLE R., LEE M., 2012. Do Foreign Bank Affiliates Cut Their Lending More Than the Domestic Banks in a Financial Crisis? Center for Applied Financial Economics (CAFE), University of Southern California.

Dell'Ariccia G., Detragiache E., Rajan R., 2008. The Real Effect of Banking Crises, Journal of Financial Intermediation 17, 89-112.

DOBRAVOLSKAS A., SEIRANOV J., 2011. Financial stability as the goal of post-crisis regulatory reforms, Business Systems and Economics 1(1).

European Central Bank database, Money, credit and banking Statisticts, retrived from http://www. ecb.europa,eu/stats/money_credit_banking/html/index.en.html [accessed: 15.03.2018].

FRANKEL J.A., SARAVELOS G., 2012. Can Leading Indicators Assess Country Vulnerability? Evidence from the 2008-2009 Global Financial Crisis. Journal of International Economics, 87(2), 216-231.

HONOHAN P., LAEVEN L. (eds.), 2005. Systemic Financial Crises: Containment and Resolution, Cambridge University Press, Cambridge.

KAMINSKY G.L., REINHART C.M., 1999. The Twin Crises: The Causes of Banking and Balance-of-Payments Problems. American Economic Review 89(3), 473-500.

KRUGMAN P., 1979. A Model of Balance-of-Payments Crises, Journal of Money, Credit, and Banking 11(3), 311-325.

LAEVEN L., VALENCIA F., 2012. Systemic Banking Crises Database: An Update. IMF Working Paper 12/163.

LAEVEN L., VALENCIA F., 2008. Systemic Banking Crises: A New Database, IMF Working Paper. WP/08/224.

Official consolidated annual report of the Raiffeisen Bank International, retrived from https://www. raiffeisen.at/oesterreich/NA-NA-NA-30-NA.html [accessed: 15.03.2018].

Official consolidated annual report of the BNP Paribas Group, retrived from https://group.bnpparibas/en/ [accessed: 15.03.2018].

Official consolidated annual report of the Crédit Agricole Group, retrived from https://www.creditagricole.com/en/ [accessed: 15.03.2018].

Official consolidated annual report of the UniCredit Group, retrived from https://www.unicredit. it/it/privati.html [accessed: 15.03.2018].

POPOV A., UDELL G.F., 2010. Cross-border banking and the international transmission of nancial distress during the crisis of 2007-2008. Working Paper Series 1203, European Central Bank, retrived from http://ideas.repec.org/p/ecb/ecbwps/20101203.html [accessed: 15.03.2018]. 
REINHART C.M., ROGOFF K.S., 2009. This Time is Different: Eight Centuries of Financial Folly, Princeton Press..

STEZHKO N.V., 2009. Impact of globalization on the spread of crisis processes in the international economy. Ukraine on the path of socio-economic transformation in the conditions of globalization: materials of the IX International scientific-practice conference - Kirovograd, KNTU, 8 .

\begin{abstract}
Summary. The article identifies post-crisis determinants of strategic management of transnational banks in the market of direct investments by means of the correlation analysis of the dependence of growth of external assets of transnational banks of European countries on the indicators of profitability and financial stability of banking systems of the countries of placement of subsidiary banks, the efficiency of the transmission mechanism of monetary policy in these countries, the structure of a complex financial crisis and the speed of post-crisis recovery of the country, ease of doing business. There is no obvious connection between the presence of foreign banks in the banking system and indicators of profitability, ease of doing business and financial stability of banking systems. This is confirmed by the correlation analysis of 45 indicators on the example of 26 European countries for 2009-2011 (the period immediately after the end of the global financial crisis of 2008-2009). It is proved that in the post-crisis period, for transnational banks, the decision of increasing/decreasing the volume of assets in the banking system of the host country is dominated by: 1) the structure of a complex financial crisis; 2) the speed of post-crisis recovery of economies and banking systems of these countries; 3 ) the effectiveness of the transmission mechanism of monetary policy in these countries.
\end{abstract}

Key words: strategic management, transnational banks, international market, financial crisis, post-crisis development.

JEL: H12, F23, G01, G15, G21.

Corresponding authors: Dmytro Tsyhaniuk, Sumy State University, Scientific and Educational Institute of Business Technologies "UABS", Department of Finance, Banking and Insurance, Petropavlivska str. 57, 40000, Sumy, Ukraine, e-mail: d.tsyhaniuk@uabs.sumdu.edu.ua; Vita Boychenko, Sumy Department of Taskombank, Pokrovska Square 2, 40000, Sumy Ukraine, e-mail: v.boichenko@tascombank.com.ua

Received: $\quad 06.04 .2018$

Accepted: $\quad 30.04 .2018$ 